\title{
Tata Kelola Pertambangan dalam Kerangka Indonesia Incorporated untuk Mewujudkan Negara Kesejahteraan
}

\author{
Oleh: Suparto Wijoyo ${ }^{1}$
}

\begin{abstract}
Abstrak
Aspek yuridis tata kelola pertambangan diformulasi memberikan konstruksi baru yang solutif bagi kesejahteraan rakyat. Tata kelola pertambangan yang baik dapat menjadikan Indonesia sebagai superkoridor ekonomi dunia melalui implementasi konsepsi Indonesia Incorporated. Gagasan ini dicitakan meneguhkan karakter NKRI sebagai negara hukum berkesejahteraan rakyat dengan memanfaatkan sumber daya pertambangan. Kajian normatif ini menghadirkan kewajiban Indonesia yang memakmurkan rakyat dari sektor pertambangan sedasar Pasal 33 UUD 1945.

Pengembangan Indonesia Incorporated dalam sistem hukum nasional dimaksudkan untuk menyelenggarakan pertambangan bervisi negara kesejahteraan. Hal ini mendorong dilakukannya penguatan pengaturan hukum sebagai basis keabsahan kebijakan pertambangan yang berkerakyatan. Tata kelola pertambangan dibingkai dalam piranti legal framework yang berkeadilan sosial sebagai manifestasi negara kesejahteraan. Kegiatan pertambangan yang tidak mensejahterakan rakyat niscaya kehilangan legitimasi filosofis (Pancasila), konstitusional (UUD 1945), dan sosial. Tata kelola pertambangan mutlak berpijak pada prinsip pembangunan berkelanjutan bagi kesejahteraan rakyat.
\end{abstract}

Kata Kunci: Indonesia Incorporated, negara hukum, negara kesejahteraan, tata kelola pertambangan, pembangunan berkelanjutan.

1 Penulis adalah Dosen Hukum Lingkungan Fakultas Hukum Universitas Airlangga, dan Koordinator Magister Sains Hukum \& Pembangunan Sekolah Pascasarjana, Universitas Airlangga 


\section{Abstract}

Legal aspect of mining governance formulated to give solutive new contraction for people welfare. Good mining governance can make Indonesia as the super corridor of world economy through implementation of Indonesia Incorporated concept. This idea was created to affirm the character of the Unitary State of the Republic of Indonesia as a rule of law on the welfare of the people by utilizing mining resources. This normative study explains Indonesia's obligation to prosper the people from the mining sector under Article 33 of the 1945 Constitution.

The development of Indonesia Incorporated in the national legal system is intended to conduct state welfare mines. It encourages the strengthening of legal arrangements as the basis for the legitimacy of a sustainable mining policy. Mining governance is framed in a legal justice framework as a manifestation of the welfare state. Mining activities that do not prosper the people undoubtedly lose philosophical legitimacy (Pancasila), constitutional (UUD 1945), and social. Mining governance absolutely stands on the principle of sustainable development for people's welfare.

Keywords: Indonesia Incorporated, state law, welfare state, mining governance, sustainable development

\section{Pendahuluan}

Berbagai referensi yuridis dan ekologis telah memberikan deskripsi faktual bahwa kekayaan tambang suatu wilayah, ternyata tidak serta-merta mensejahterakan rakyat di daerah yang kaya bahan tambang. ${ }^{2}$ Kompleksitas permasalahan semakin rumit dengan memasuki masa transisi atas berlakunya Undang-undang No. 23 Tahun

2 Berbagai pemberitaan media massa dapat dirujuk dan dapat dibaca Sukarno, Indonesia Menggugat: Pidato Pembelaan Bung Karno Dimuka Hakim Kolonial, SK. Seno, Djakarta, 1956, h. 63-67. Ignatius Haryanto dkk (Editor), Kehutanan Indonesia Pasca Soeharto: Reformasi Tanpa Perubahan, Pustaka Latin, Jakarta, 1998, h. 11-46. Kerry B. Collison, Indonesia Gold, Sid Harta Publishers, Australia, 2002, h. 449-486. Leontine E. Visser dan Amapon Jos Marey, Bakti Pamong Praja Papua, Kompas, Jakarta, 2008, h. 335-360. Freddy Numberi, Quo Vadis Papua, PT. Buana Ilmu Populer, Jakarta, 2013, h. 187-258 Frento T. Suharto, Menambang Kekayaan Dari Bisnis Emas Tanpa Mengeruk Alam, PT Elex Media Komputindo, Jakarta, 2014, h. 87-101. Suparto Wijoyo, Reklamasi itu Kebutuhan Siapa, Forum Keadilan, No. 22, 16 Oktober 2016. Weekly Sindo, Uji Nyali Freeport, No. 52 Tahun V, 27 Februari-5 Maret 2017. 
2014 tentang Pemerintahan Daerah (UU Pemda). Konflik kewenangan dan orientasi ekonomi menyelimuti pengelolaan pertambangan yang tidak menguntungkan rakyat dengan penegakan hukum (lingkungan) yang sangat lemah. ${ }^{3}$

Pemerintah daerah kabupaten/kota tidak pula memberikan fasilitasi dengan melakukan pengorganisasian para penambang liar untuk diberikan solusi yuridis, ekonomis dan ekologis sesuai dengan kaedah pembangunan berkelanjutan (sustainable development). Pengabaian pengakuan terhadap hak-hak masyarakat lokal, khususnya masyarakat hukum adat acapkali masih terjadi. Benturan kepentingan antara penduduk lokal dengan perusahaan tambang merupakan fenomena harian yang seringkali terlambat direspon, sehingga menimbulkan disharmoni sosial.

Berbagai realitas pertambangan telah mendiskripsikan pula kurangnya pendayagunaan sarana administrasi (dalam klausula perizinan) maupun instrumen ekonomi yang berupa jasa lingkungan dan jaminan reklamasi sebagai sarana legal pengelolaan pertambangan yang berwawasan lingkungan. Di banyak daerah justru instansi pemerintah kabupaten/kota tidak menginternalisir biaya lingkungan sebagai bagian dari manajemen pertambangan. ${ }^{4}$ Kenyataan ini sangat rentan dengan tindakan korupsi di bidang pertambangan berupa pungli terhadap alat angkut maupun volume bahan tambang.

Terdapat pula kecenderungan bahwa kepala daerah kabupaten/kota melakukan pembiaran atas kerusakan areal pertambangan hanya semata-mata karena alasan kewenangan yang sudah beralih ke pemerintah provinsi. Padahal pejabat yang membiarkan kerusakan ekosistem berdasarkan Undang-undang No. 32 Tahun 2009 tentang Perlindungan dan Pengelolaan Lingkungan Hidup (UU PPLH), dapat dikualifikasi sebagai pejabat yang melakukan tindakan kejahatan

3 Suparto Wijoyo, Penyelesaian Sengketa Lingkungan (Environmental Disputes Resolution), AUP, Surabaya, Cetakan Kedua, 2005, h. 19-86. Suparto Wijoyo, Refleksi Matarantai Pengaturan Hukum Pengelolaan Lingkungan Secara Terpadu, AUP, Surabaya, 2005, h. 4-14. Suparto Wijoyo, Karakteristik Hukum Acara Peradilan Administrasi, AUP, Surabaya, Cetakan Kedua, 2005, h. 34-67. Suparto Wijoyo, Kusebut Indonesia: Dari Keanekaragaman Menuju Keseragaman Hayati, AUP, Surabaya, 2012, h. 45-78. Kementerian Lingkungan Hidup, Himpunan Hasil-hasil Putusan Pengadilan Tentang Tindak Pidana Lingkungan, KLH, Jakarta, 2007.

4 Suparto Wijoyo, Birokrasi Pungli Menghambat Biocracy, Koran Sindo, 25 Oktober 2016. Suparto Wijoyo, Menggugat Makna Negara, Jawa Pos, 1 November 2016. Suparto Wijoyo, Pentas Hukum dan Keadilan, Jawa Pos, 16 Desember 2016. Suparto Wijoyo, Menggugat Negara Soal Banjir, Jawa Pos, 13 Maret 2017. 
lingkungan. ${ }^{5}$ Kenyataan demikian semakin memperburuk potret pertambangan nasional di kancah perkembangan dunia yang sangat ekstrim. ${ }^{6}$

Kondisi faktual dunia saat ini menunjukkan adanya: pengurasan energi yang terus diperebutkan, keamanan yang mengancam, konflik dan peperangan yang masih mewarnai berbagai belahan bumi, bencana alam dan jihadist war, pertumbuhan penduduk dan culture war, krisis pangan dan indentitas, terutama kemiskinan yang melanda disetiap segmen geografis dunia. ${ }^{7}$ Terhadap hal ini terdapat tulisan lama James Goldsmit, The Trap yang disampaikan dihadapan 2000 orang di Grand Amphitheatre Universitas Sorbonne, Paris bahwa: ${ }^{8}$

Setiap masyarakat di dunia modern sedang menghadapi problem rumit dan tidak ada solusi yang sederhana dan universal. Tetapi banyak di antara problem ini memiliki akar yang sama. Ilmu, teknologi dan ekonomi telah diperlakukan oleh masyarakat modern ini sebagai tujuan itu sendiri, bukannya sebagai sarana penting untuk meningkatkan kesejahteraan.

Meningkatnya pengangguran, kekerasan, kemiskinan, kemerosotan lingkungan dan kesadaran umum bahwa telah terjadi kesalahan yang mendasar dalam pengelolaan perekonomian negara seperti yang dilansir James Goldsmit tersebut telah sampai pada tataran merenungkan kembali keberadaan negara kesejahteraan yang dalam ungkapan Bjorn Hettne: Negara Kesejahteraan Dipertanyakan. Peran negara dan pemerintah untuk mensejahterakan rakyat harus ditata kembali dengan menyodorkan Paradigma Theory \& Policy Making dalam lingkup Good Corporate Governance. Dinamika dunia memang turut menentukan pergerakan ekonomi suatu bangsa. ${ }^{9}$ Kebijakan pertambangan untuk kesejahteraan

5 Suparto Wijoyo, Tak Lelah Dirundung Bencana, Jawa Pos, 28 Desember 2016. Suparto Wijoyo, Negara Hukum Dalam Daulat Kuasa, Jawa Pos, 14 Januari 2017.

6 Diolah dari pemikiran James Canton, The Extreme Future, Alvabet, Jakarta, 2010, hlm. 68.

7 Daniel, Yergin The Quest: Energy, Security, and the Remaking of the Modern World, The Penguin Press, New York, 2011. George Friedman, The Next 100 years, Anchor Books, New York, 2009. Thomas L. Friedman, The World Is Flat: Sejarah Ringkas Abad Ke-21, Dian Rakyat, Jakarta, 2006, h. 67-98.

8 James Goldsmith, Perangkap, Yayasan Obor Indonesia, Jakarta, 1996, h.3. Suparto Wijoyo, Menyoal Legitimasi Reklamasi, Kompas, 4 Oktober 2016.

9 Bjorn Hettne, Teori Pembangunan Dan Tiga Dunia, PT. Gramedia Pustaka Utama, Jakarta, 2001. Iida, Akira, Paradigm Theory \& Policy Making: Reconfiguring The Future, TUTLE, 2004, h. 23-36. Eric Schlosser,, Command And Control, The Penguin Press, New York, 2013. Nicholas Mousis,, Guide to European Policies, 6th edition, European Study Service, BP29-B-1330 Rixensart, Belgium, 2000, h. 67-90. Meene van de, Ineke and Benjamin van Rooij, Access to Justice And Legal Empowerment: Making the Poor Central in Legal Development Co-operation. Leiden University Press. 
rakyat, meminjam bahasa Alan Gart dirumuskan dalam ranah RDR, yaitu: Regulation-Deregulation-Reregulation..$^{10}$ Dengan RDR berarti konsepsi GCG (Good Corporate Governance) sebagai tuntutan tata kelola pemerintahan modern tetap berada dalam kerangka welfare state yang tetap bertumpu pada negara hukum (rechtsstaat) sebagaimana diamanatkan UUD 1945. Permasalahannya adalah: bagaimanakah mengimplementasikan konsepsi yuridis Indonesia Incorporated dalam tata kelola pertambangan untuk mewujudkan kesejahteraan rakyat? ${ }^{11}$

\section{Good Corporate Governance (GCG) Sektor Pertambangan Dalam Konstelasi Bernegara}

Konsepsi Good Corporate Governance (GCG) merupakan produk dari perkembangan sejarah bernegara melalui peraturan perundang-undangan. Dasar pemikiran ini dapat digambarkan sebagai berikut:

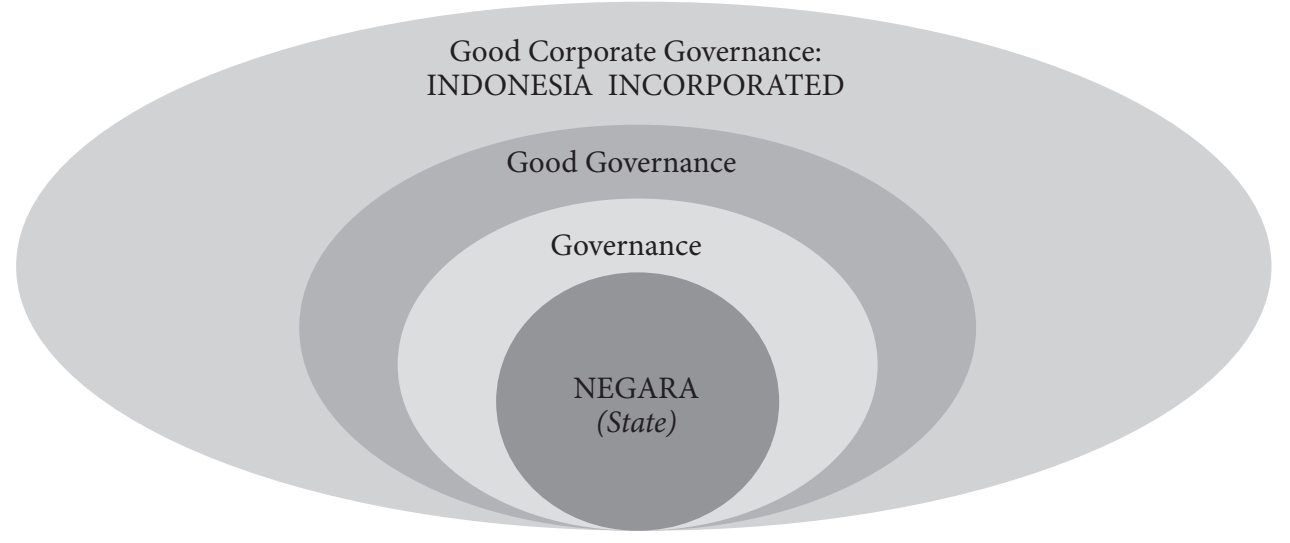

Gambar 1: Evolusi Pergerakan GCG Menuju Indonesia Incorporated

Negara sebagai "a society politically organized" yang dalam pemikiran J.J. Rousseau (1712-1778) merupakan resultan "The Social Contract", tersusun

10 Gart, Alan, Regulation, Deregulation, Reregulation: The Future of the Banking, Insurance, and Securities Industries, John Wiley \& Sons, Inc, 1994. Wijoyo, Suparto, Ilmu Hukum, Airlangga Universy Press, Surabaya, 2005, h. 37-47.

11 Pengkajian ini juga diinspirasi pembahasan dalam Al Gore, The Future, A Random House Group Company, 2013. Robert C. Guell,, Issues in Economics Today, McGraw-Hill, 2012. Tom Gorman, The Complete Ideal's Guides, Economics, Prenada, 2009, 87-90. 
atas elementasi wilayah, rakyat, pemerintah maupun kedaulatan. Pemerintah mengimplementasikan tujuan negara secara terorganisir ${ }^{12}$ dengan melakukan tata kelola pemerintahan (governance) guna menjalankan tugas fungsional: "selforganizing, interorganizational networking" yang berkarakter "interdependence, resource-exchange, rule of the game, and significant autonomy from the state". ${ }^{13}$ Tata kelola negara dalam konsepsi governance pada perkembangannya harus mampu menyelenggarakan kepentingan publik.

Sektor publik akhirnya menjadi pusat perhatian tata kelola pemerintahan ("governance") yang kemudian mendapatkan tambahan atribut "yang baik", sehingga disebut "good governance". Negara pada akhirnya harus diterima sebagai kenyataan publik untuk menjadi bagian integral yang saling bersinggungan pada ruang governance dalam hubungan antar sektor: ${ }^{14}$

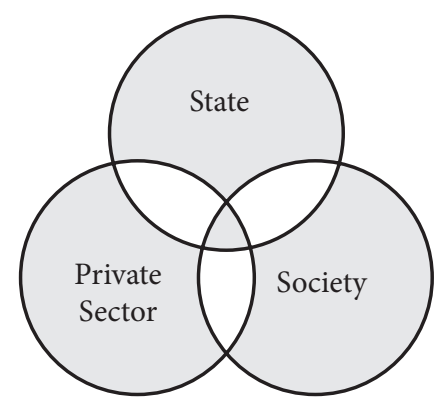

Gambar 2: Hubungan Antarsektor dalam Good Governance

12 Lihat Algra, N.E., at., all., Profiel van het Recht, Kluwer, 1999. Ash Garton, Timothy, Free World: America, Europe and the Surprising Future Of The West, Random House, Inc., New York, 2004, 104-157. Friedmann, W., The State And The Rule Of Law in a Mixed Economy, Stevens \& Sons, London, 1971., h. 2-5. Francis Fukuyama, Kemenangan Kapitalisme dan Demokrasi Liberal, Qalam, Yogyakarta, 2001, h. 89-128.

13 Baca Francis E. Rourke, Bureaucracy Politics, and Public Policy, Little, Brownand Company, Boston, 1976. Geoffrey Samuel,, The Foundations of Legal Reasoning, MAKLU, 1994. Ruud Lubbers, at.all., Inspiration for Global Governance: The Universal Declaration of Human Rights and the earth Charter, Kluwer, 2008. Miriam Budiardjo, Dasar-Dasar Ilmu Politik, Gramedia, Jakarta, 2015.

14 Lembaga Administrasi Negara dan Badan Pengawasan Keuangan dan Pembangunan, Akuntabilitas dan Good Governance, Jakarta, 2000, h. 6-7. Laurence Boulle,, The Law Of Globalization An Introduction, Wolters Kluwer, 2009. Gill, Indermit S., and Todd Pugatch, At the Frontlines of Development Reflection From the World Bank, The World Bank, D.C., 2005. Soekarwo, Meneguhkan Demokrasi Musyawarah Demi Kesejahteraan Rakyat, Orasi Pelantikan, Gedung Negara Grahadi, Surabaya, 2014. Ibid. Jimoh Omo-Fadaka, Development From Within, Dialogue, Vol. 11 No. 2, 1978, h. 59. Daoed Joesoef, Industrialisasi dan Pembangunan Manusia Pembangunan, dalam CSIS, Industrialisasi Dalam rangka Pembangunan nasional, Jakarta, 1982, h. 94. A.G. Pringgodigdo, Perjuangan Bangsa Indonesia Menegakkan Pancasila Dalam Masa Penjajahan/Pendudukan Jepang, dalam Santiaji Pancasila, h.174. 
UNDP memaparkan good governance sebagai hubungan yang sinergis dan konstruktif antara negara, sektor privat dan masyarakat dengan mengajukan karakteristik berikut ini: ${ }^{15}$

1. Participation, setiap warga negara mempunyai suara dalam pembuatan keputusan, baik secara langsung maupun melalui intermediasi institusi legitimasi yang mewakili kepentingannya. Partisipasi seperti ini dibangun atas dasar kebebasan berasosiasi berbicara serta berpartisipasi secara konstruktif.

2. Rule Of Law, kerangka hukum harus adil dan dilaksanakan tanpa pandang bulu, terutama hukum untuk hak asasi manusia.

3. Transparency, transparansi dibangun atas dasar kebebasan arus komunikasi. Proses-proses, lembaga-lembaga dan informasi secara langsung dapat diterima oleh mereka yang membutuhkan. Informasi harus dapat dipahami dan dapat dimonitor.

4. Responsiveness, lembaga-lembaga dan proses-proses harus mencoba melayani setiap stake holders.

5. Consensus Orientation, good governance menjadi perantara kepentingan yang berbeda untuk memperoleh pilihan terbaik bagi kepentingan yang lebih luas baik dalam hal kebijakan-kebijakan maupun prosedur-prosedur.

6. Equity, semua warga negara, baik laki-laki maupun perempuan, mempunyai kesempatan untuk meningkatkan atau menjaga kesejahteraan mereka.

7. Effectiveness and Efficiency, proses-proses dan lembaga-lembaga menghasilkan sesuai dengan apa yang telah digariskan dengan menggunakan sumbersumber yang tersedia sebaik mungkin.

8. Accountability, para pembuat keputusan dalam pemerintahan, sektor swasta dan masyarakat (civil society) bertanggungjawab kepada publik dan lembagalembaga stake holder. Akuntabilitas ini tergantung pada organisasi dan sifat keputusan yang dibuat, apakah keputusan tersebut untuk kepentingan internal atau eksternal organisasi.

9. Strategic vision, para pemimpin dan publik harus mempunyai perspektif "good governance" dan pengembangan manusia yang luas dan jauh kedepan sejalan dengan apa yang diperlukan untuk membangun hal semacam ini.

15 LAN, op.cit. 
Terdapat pemahaman esensial tentang "good governance" yang mencerminkan ketertiban antarsektor dengan enam elemen utama "good governance" yang berupa: The Rule of Law; The Rule of Integrity; The Rule of Transparency; The Rule of Participation; The Rule of Accountability; dan The Rule of Value for Money. ${ }^{16}$ Tatanan pemerintahan yang berbasis prinsip good governance ini kemudian berkembang dalam wadah paradigmatik "good corporate governance" (GCG). Government yang bersendikan GCG harus memperhatikan: "aturan main”, integritas, transparansi, partisipasi, akuntabilitas dan bervisi keuangan secara yuridis tengah memasuki tren ekonomi pada pusaran globalisasi yang dapat penulis gambarkan sebagai berikut:

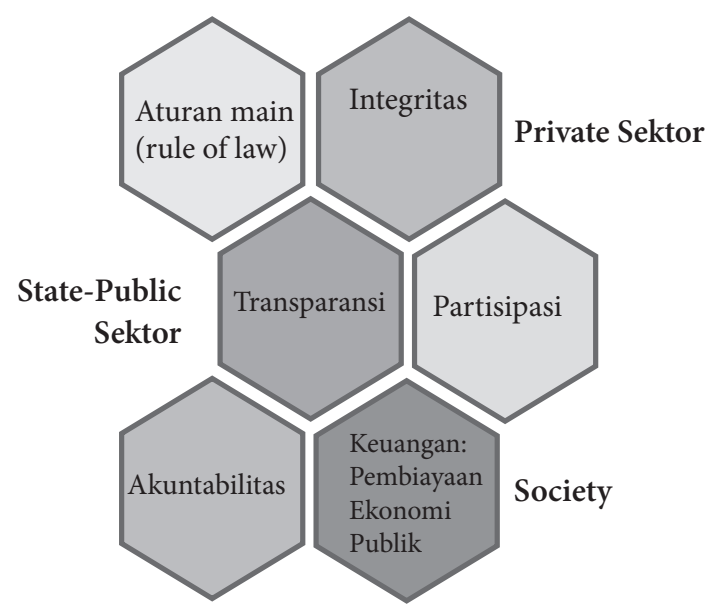

Gambar 3: Karakter Substansial GCG

Tata kelola pemerintahan tidak lagi dapat dilihat secara parsial dan tradisional. Sektor-sektor kehidupan publik yang menyangkut state tidak bisa lagi dilakukan menurut standar organisasi pemerintahan konvensional, tetapi dengan menerima kenyataan bahwa negara telah hadir sebagai "korporasi" yang menggerakkan ekonomi global-nasional-lokal. Pergerakan ekonomi yang saling mempengaruhi ini menandakan lahirnya public-sector reform dalam kerangka "corporation", terutama bidang perekonomian sebagai sektor yang sangat menguasai public-interest (dalam bahasa Pasal 33 UUD 1945 “... yang menguasai hajat bidup orang banyak ...”).

16 The Civil Service Commission, Thailand, 1999. Sebagai tambahan Suparto Wijoyo, Hukum Lingkungan di Antara Para Pemalas, AUP, Surabaya, 2012, h. 68-143. 
GCG hadir mendorong ekonomi global terus bergulir, termasuk di sektor pertambangan nasional, ${ }^{17}$ dan melahirkan "the emerging global economy" di berbagai negara. ${ }^{18}$ Ekonomi dunia dengan sendirinya bergerak menuju apa yang dinamakan "breaking boundaries", dan hadirlah "competition policy in a change world" perdagangan dalam segala tingkatannya. ${ }^{19}$ Tata kelola pertambangan model Undang-undang No. 4 Tahun 2009 Tentang Pertambangan Mineral dan Batubara (UU Minerba) dalam dinamikanya wajib membuka ruang "politic and social opportunities" sebagai bagian dari pengambilan "the strategy and the feasibility of (Toward) Social Welfare" untuk kepentingan Rakyat. Negara dengan struktur birokrasi dalam membentuk public policy mesti menyadari untuk selalu melakukan improvement sebagai suatu korporasi guna membangun corporate culture for sustainable growth, karena memang selalu ada development challenges..$^{20}$

\section{Fungsi Negara Sebagai Korporasi Untuk Mewujudkan Indonesia Incorporated Sektor Pertambangan}

Sebagaimana negara-negara lain di dunia yang merumuskan tujuan negara dalamkonstitusinya, Indonesiamenetapkantujuannegarayangsecarakonstitusional harus diwujudkan. Tujuan NKRI dituangkan dalam Pembukaan UUD 1945 adalah “... melindungi segenap bangsa Indonesia dan seluruh tumpah darah Indonesia dan untuk memajukan kesejahteraan umum, mencerdaskan kehidupan bangsa, dan ikut melaksanakan

17 Soekarwo dkk, Pakde Karwo Pintu Gerbang MEA 2015 Harus Dibuka, Kencana, Prenada Media Group, Jakarta, 2015, h. 545-580. The Wordlwatch Institute, State Of The World Our Urban Future, W.W. Norton \& Company, New York-London, 2006, h. 67-98. Kohli, Atul, State-Directed Development, Political Power and Industrialization in the Global Periphery, Cambridge University Press, 2004, h. 109-116.

18 Merit E. Janow, at.all., The WTO: Governance, Dispute Settlement \& Developing Countries, Juris Publishing, Inc., 2008. Hwan-Yun Kim, Local Government Finance and Bond Markets, Asian Development Bank, 2003. Suparto Wijoyo, Otoda Dari Mana Dimulai?, AUP, Surabaya, 2005, 25-63.

19 Joseph E. Pattison, Breaking Boundaries, Peterson's Book, New Jersey, 1996. Nicholas Moussis, Guide To European Policies, European Study Service, 2000. Suatu bacaan yang menarik mengenai hal ini juga adalah Laurence Boulle,, The Law Of Globalization An Introduction, Wolters Kluwer, 2009, h. 67-90.

20 Robert C. Guell, Issues in Economics Today, McGraw-Hill, 2012. Jerald Hage, and Charles H. Powers, Post-Industrial Lives: Roles and Relationships in the 21st Century, SAGE, London, 1992, h. 32-57. CHR. Jimmy L. Gaol, A to Z, Human Capital: Manajemen Sumber Daya Manusia: Konsep, Teori, Dan Pengembangan Dalam Konteks Organisasi Publik Dan Bisnis, PT. Grasindo, Jakarta, 2014, h. 76-98. Pakde Karwo, Pintu Gerbang ... op.cit., h. 3-34. 
ketertiban dunia yang berdasarkan kemerdekaan, perdamaian abadi dan keadilan sosial ...". Tujuan ini mendapatkan landasan ideologis bahwa pencapaiannya harus dipandu dengan dasar filosofis (philosofische gronslag) Pancasila.

Pemerintah mendapatkan amanat ideologis dan konstitusional untuk mewujudkan tujuan negara dengan konsepsi yang dewasa ini memasuki babak GCG. Terhadap hal ini secara yuridis-ekonomi terdapat pemikiran sistematis yang disodorkan W. Friedman dalam The State and The Rule of Law in A Mixed Economy. Dikemukakan bahwa terdapat empat fungsi negara dalam ekonomi campuran yang dapat digambarkan dengan grafis seperti di Gambar $4 .^{21}$

Keempat fungsi negara bukan untuk dibenturkan tetapi disinergiskan, terutama di sektor pertambangan. Negara dibentuk memang untuk menyediakan layanan publik (public-services) bagi rakyatnya dengan fungsi provider, sekaligus harus mengendalikan perilaku ekonomi dalam bingkai fungsi controller, termasuk pada aktivitas badan usaha milik negara (BUMN) - public sectors atau swasta (BUMS) - private sector, karena negara berfungsi selaku entrepreneur dengan tetap menjamin keadilan bagi seluruh pelaku ekonomi, mengingat negara memangku juga fungsi umpire.

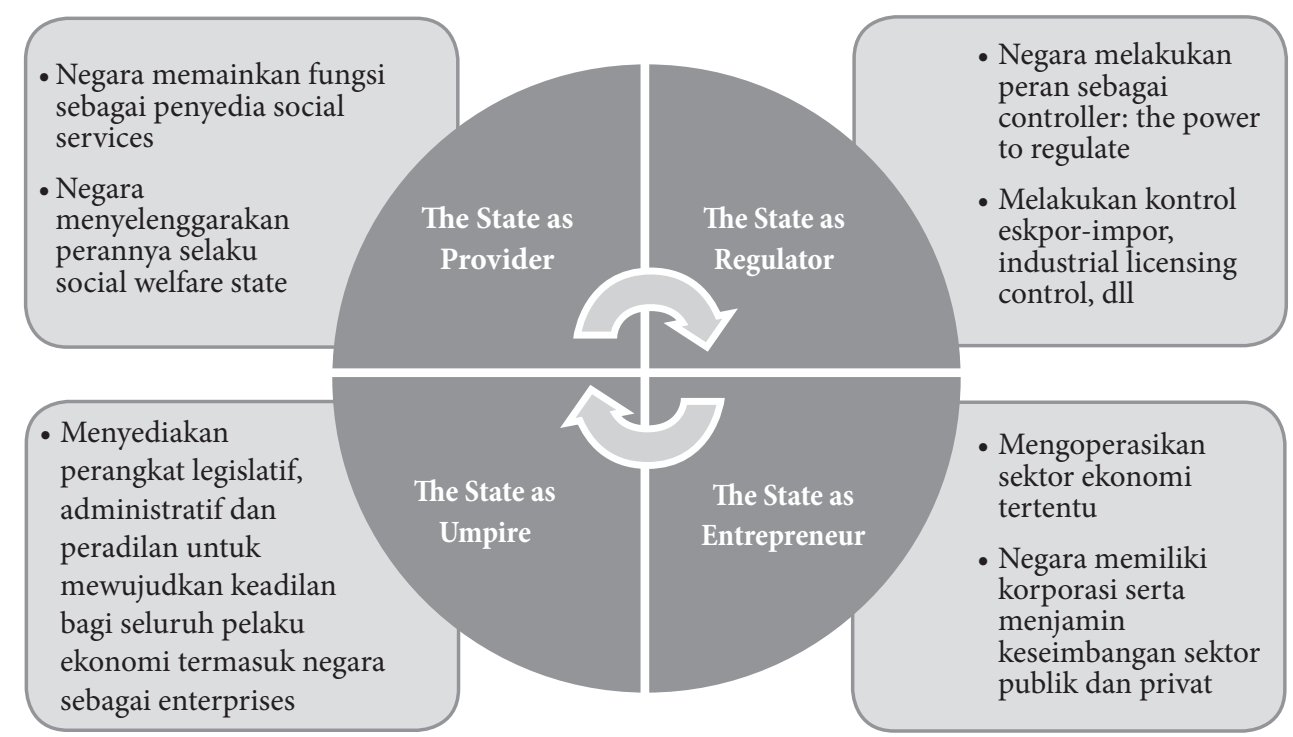

Gambar 4: Fungsi Negara dalam Pembangunan Ekonomi

21 Diolah dari pemikiran W. Friedmann, The State And The Rule Of Law in a Mixed Economy, Stevens \& Sons, London, 1971, h. 24-99. 
Negara memainkan peran dalam menciptakan keseimbangan seluruh dunia usaha (enterprise) agar "public and private power" tidak saling menjatuhkan, tetapi mendukung demi terwujudnya "balance between public and private enterprise". Fungsi NKRI secara ekonomi dalam pikiran W. Friedmann sebenarnya telah diformulasikan UUD 1945. Norma hukum yang tercermin dalam Pasal 33 UUD $1945^{22}$ memberi pesan fundamental mengenai penyelenggaraan perekonomian nasional “... yang penting bagi negara dan yang menguasai hajat hidup orang banyak dikuasai oleh negara; kekayaan alam yang terkandung di dalamnya dikuasai oleh negara dan dipergunakan untuk sebesar-besar kemakmuran rakyat; dan perekonomian nasional diselenggarakan berdasar atas demokrasi ekonomi dengan prinsip kebersamaan, efisiensi berkeadilan, berkelanjutan, berwawasan lingkungan, kemandirian, serta dengan menjaga keseimbangan kemajuan dan kesatuan ekonomi nasional".

Pasal 33 UUD 1945 mengalirkan pandangan bahwa pada hakekatnya negara harus hadir dan dirasakan keberadaannya oleh rakyat. Dalam perkembangan perekonomian global sejak abad ke-20 dan awal abad ke-21 ini, jelaslah bahwa the state as entrepreneur-corporation yang bertumpu pada prinsip-prinsip GCG berkewajiban memberi yang terbaik pada rakyatnya. Cita konstruktif demikian dalam tindakan negara dihadirkan untuk "melayani rakyat" layaknya hubungan "produsen-konsumen" atau "korporasi bisnis dengan customers". Hubungan demikian mengacu pada bahasa David Straker masuk pada lingkup The Quality Conspiracy. Negara sebagai korporasi memberikan jaminan mutu hidup yang berkualitas kepada rakyat yang multi perspektifnya diolah dari David Straker dan tersajikan berikut ini: ${ }^{23}$

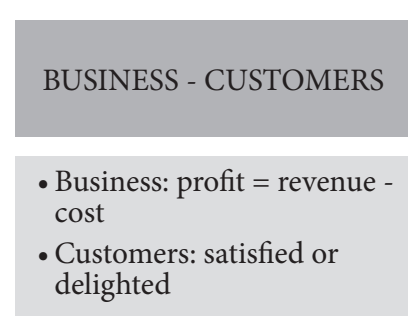

\section{Gambar 5: Mutu Hidup yang Berkualitas Bagi Rakyat}

PEMBERIAN TERBAIK:

TOTAL OFFERING PROCESSES

- Total Offering: superior product + price + delivery + communication

- Processes:effective and efficient

\section{PEOPLE - LEADERSHIP}

- People: able and motivated

- Leadership: committed and consistent

22 Terhadap hal ini sebaiknya dibaca Mohammad Hatta, Penjabaran Pasal 33 UUD '45, Mutiara, Jakarta, 1980. Mohammad Hatta, Politik, Kebangsaan, Ekonomi (1926-1977), Kompas, 2015. Mohammad Hatta, Membangun Koperasi dan Koperasi Membangun: Gagasan \& Pemikiran, Kompas, 2015. LP3ES, Karya Lengkap Bung Hatta, Jakarta, 2015, 43-98.

23 Diolah dari pemikiran dan gagasan Straker, David, The Quality Conspiracy, Gower, 1998, h. 12-53. 
Pikiran dasar yang ditawarkan David Straker dapat menjadi pedoman yang dapat digunakan untuk menyelenggarakan tata kelola pertambangan dengan melakukan "policy change in public sector reforms". 24 GCG yang dibarengi dengan kemampuan paradigmatik keterpaduan pengelolaan ekonomi negara secara korporatif yang integral menjadikan model Good Corporate Governance System sebagai GCG integratif, dimana dominasi keterpaduan menjadi orientasi penting membangun pertambangan nasional. Interkoneksi antar sektor ekonomi maupun antar wilayah dibangun dengan komitmen dan konsistensi kepemimpinan yang mampu memberikan "jalan alternatif" (jalan lain) adanya keterpaduan fungsifungsi negara sebagai provider, regulator, dan korporasi maupun wasit. Pola pemikiran ini digambarkan sebagai berikut: ${ }^{25}$

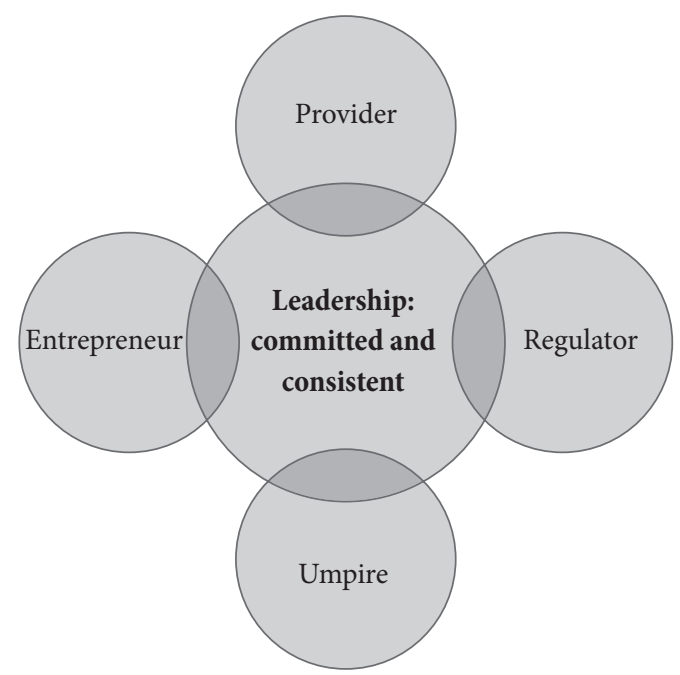

Gambar 6: Kepemimpinan dalam Keterpaduan Fungsi Negara

Tindakan pemerintahan tidak boleh terpisah dengan kebutuhan publiknya (integral bestuur), karena semua urusan negara menjadi tanggungjawab pemerintah yang menyentuh kepentingan pasar dengan tindakan yang patut ("behoorlijkheid"). Dengan demikian negara melakukan pengaturan ("command") dan pengawasan

24 Sebagai tambahan dapat dibaca Jacques Laffont, Jean, Regulation and Development, Cambridge University Press, UK, 2005. Richard J. Pierce, JR, Regulated Industries In A Nutshell, West Publishing CO, 1984, h. 56-99.

25 Diolah dari berbagai referensi, Jonah Goldberg, Liberal Fascism: The Secret History of the American Left from Mussolini to the Politics of Meaning, Doubleday, 2007, h. 154-212. Tom Gorman, The Complete Ideal's Guides, Economics, Prenada, 2009. Habermas Jurgen, Teori Tindakan Komunikatif Buku Satu: Rasio dan Rasionalisasi Masyarakat, Kreasi Wacana,Bantul, 2012. Craig Burnside, (Editor), Fiscal Sustainability in Theory and Practice, The World Bank Washington D.C., 2005. 
("control") dalam segala dimensinya, khususnya jalannya perekonomian agar tetap terjamin adanya "the stability and the sustainability". ${ }^{26} \mathrm{Hal}$ demikian harus dibarengi dengan perubahan paradigma pemimpin yang secara psikologis menurut Carol S. Dweck lazim disebut "change your mindset change your life". Pengelola kekayaan tambang harus membuka diri dari keterikatan birokratik yang kaku menjadi birokrat yang responsif. ${ }^{27}$

Untuk memudahkan pemahaman atas peran birokratik dalam pemerintah yang terpadu dalam mempersiapkan hadirnya (state) incoproprated sektor pertambangan adalah dengan cara: (i) membangun tata kelola pemerintahan yang terpadu dalam segala prosedur birokratiknya; (ii) memberikan jaminan stabilitas ekonomi dengan pertumbuhan dan pemerataan yang inklusif; (iii) pasar yang kondusif bagi produksi pertambangan dengan daya beli masyarakat yang terus bergerak serta infrastruktur yang memadai; (iv) jajaran birokrasi yang responsif dengan kemudahan pelayanan yang ramah investasi; dan (v) pengaturan yang berkepastian hukum dengan implikasi negatifnya berupa persepsi munculnya "negara yang terlalu turut campur".

Manajemen pertambangan yang mengkorporasikan fungsi negara memang akan menimbulkan kesan hadirnya "interventionist state". ${ }^{28}$ Terhadap hal demikian ini dapat dikemukakan pandangan $\mathbf{W}$. Friedmann di atas yang menyebut negara aktif ("the active state"). Negara memang harus aktif atau responsif (dalam ungkapan leluhur "tanggap ing sasmito") dalam melayani rakyat melalui regulasi untuk mengatasi problem "equality and fair competition" di sektor pertambangan. Penataan ini tentu saja dengan jejaring "administrative justice" maupun "government policy". ${ }^{29}$

26 Beberapa pustaka dapat dirujuk, antara lain A.J. Hoekema et.al., Integraal Bestuur, Amsterdam University Press, 1998, h. 67-98. R. Crince Le Roy,, Bestuur en Norm, Kluwer-Deventer, 1986, h. 12-45. Richard A. Posner, Economic Analysis Of Law, Little, Brown and Company, 1992. Heemskerk W.H., Vorm en Wezen, Uitgeverij LEMMA B.W., Utrecht, 1991.

27 Carol S. Dweck,, Cara Baru Melihat Dunia Dan Hidup Sukses Tak Berhingga, Serambi Ilmu Semesta, 2007.

28 Secara khusus dapat dibaca Jonah Goldberg, Liberal Fascism: The Secret History of the American Left from Mussolini to the Politics of Meaning, Doubleday, 2007. Michel Foucault, Kegilaan dan Peradaban, Madness and Civilization, Ikon Teralitera, Yogyakarta, 2002, h. 67-98.

29 Fritjof Capra, Titik Balik Peradaban: Sains, Masyarakat dan Kebangkitan Kebudayaan, Yayasan Bentang Budaya, Yogyakarta, 1997, 145-187. Graydon Carter,, What We've Lost, Little, Brown, 2004 Kerry B. Collison,, Indonesian Gold, Sid Harta Publishers, Australia, 2012. Budi Sulistyo, dkk., MDGs Sebentar Lagi: Sanggupkah Kita Menghapus Kemiskinan Di Dunia?, KOMPAS, Jakaarta, 
Kecenderungan tata kelola tambang dengan konstruksi GCG harus dibarengi leadership yang berkomitmen mensejahterakan rakyat dalam figur Indonesia Incorporated. Negara dikorporasikan dalam makna tata kelolanya yang mampu memadukan antara sektor publik-privat dan sosial. Dalam lingkup demikian terdapat tulisan Declan Hayes, Japan's Big Bang: The Deregulation and Revitalization of The Japanese Economy yang mengulas secara komprehensif mengenai Japan Inc. ${ }^{30}$

Kehadiran Jepang sebagai supremasi ekonomi dunia melalui export-oriented products: cars, cameras, electrical goods dan sebagainya tidak lepas dari perombakan paradigma perekonomiannya menjadi Japan Incoporated. Ekonomi dibangun dengan membuka akses dan kesempatan untuk mentransformasi corporate culture antara dunia usaha publik-privat dan sosial. Pemerintah mengambil peran sebagai pembuat kebijakan ekonomi yang tergolong "overall guidelines" sebagai wujud "government-guaranteed" yang dituangkan dalam wujud "administrative guidance". Konstruksi Japan Inc. terbangun dengan sikap solidaritas kelompok dan pemimpin yang cerdas serta patriotik sebagai syarat utamanya. ${ }^{31}$

Sektor publik

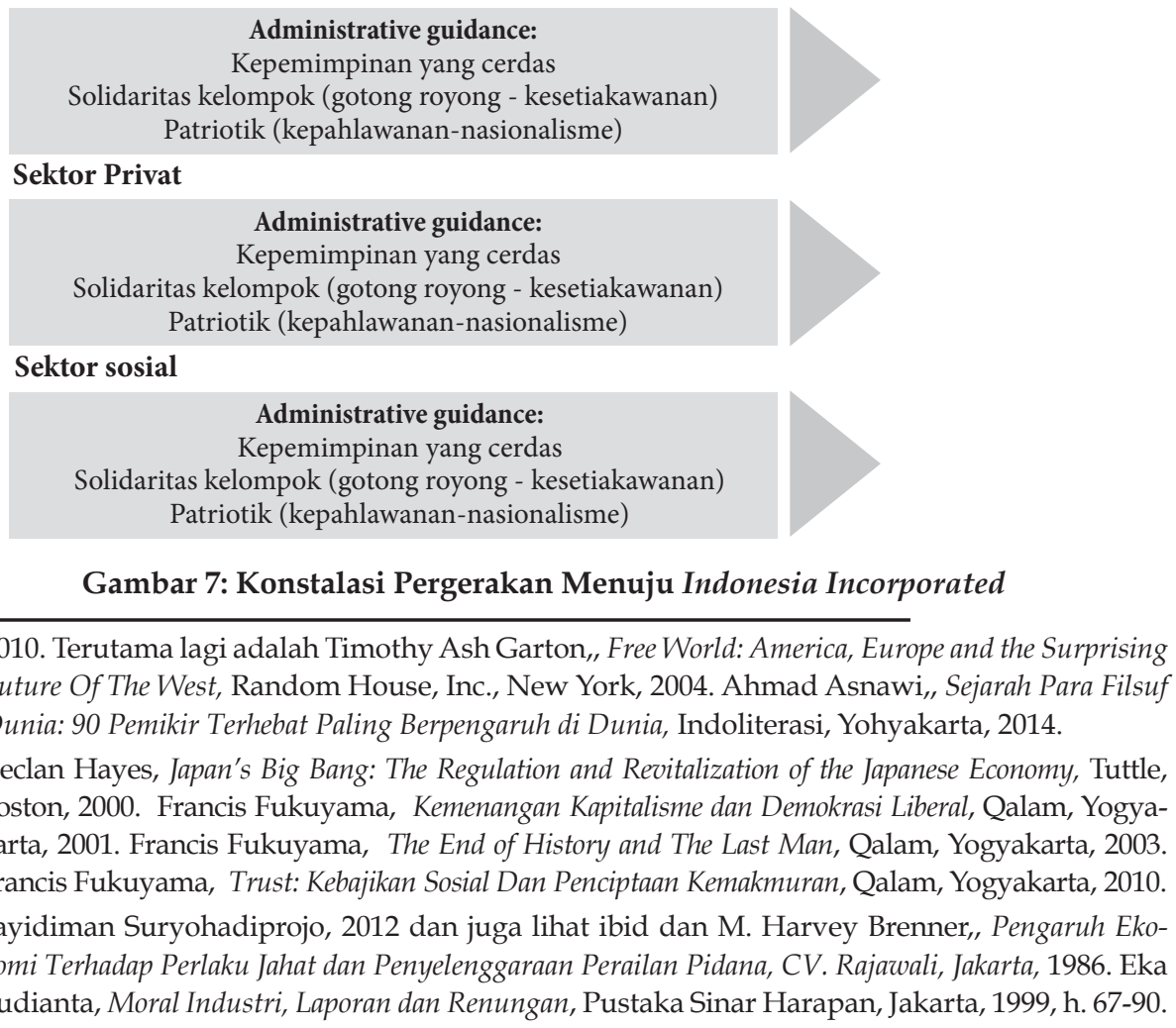


Makna suatu negara menjadi incorporated dengan rumusan konsepsional administrative guidance; kepemimpinan yang cerdas; solidaritas kelompok, dan patriotisme tertuang dalam Gambar 7 tersebut. UUD 1945 memberikan optimisme bahwa Indonesia Incorporated dapat diwujudkan karena masyarakat Indonesia sesungguhnya memiliki watak dasar yang dipersyaratkan dalam tatanan Indonesia Incorporated tersebut, yaitu: solider (kesetiakawanan dan gotong royong), serta patriotik (kepahlawanan-nasionalisme) dengan kepemimpinan yang visioner. ${ }^{32}$ Regulasi pertambangan dalam jiwa Indonesia Incorporated harus bermanfaat dan berorientasi kesejahteraan rakyat. Praktik pertambangan selama ini belum memberikan "kesejahteraan rakyat" sesuai Pasal 33 UUD 1945.

Kreasi hukum pertambangan dalam kontektualitas Indonesia Inc. disusun sesuai dengan esensi negara kesejahteraan dengan hukum yang berkeadilan. Ini merupakan wujud pengembangan corporate culture, solidaritas atau gotong royong serta patriotisme alias nasionalisme. Sehubungan dengan hal ini, nilai-nilai kepercayaan menjadi penentu langkah praktis yang terus dikembangkan guna merealisasi agenda kolektif terwujudnya Indonesia Inc. Langkah dan upaya itu selanjutnya dilakukan dengan memperkuat moralitas segitiga timbal balik berikut ini:

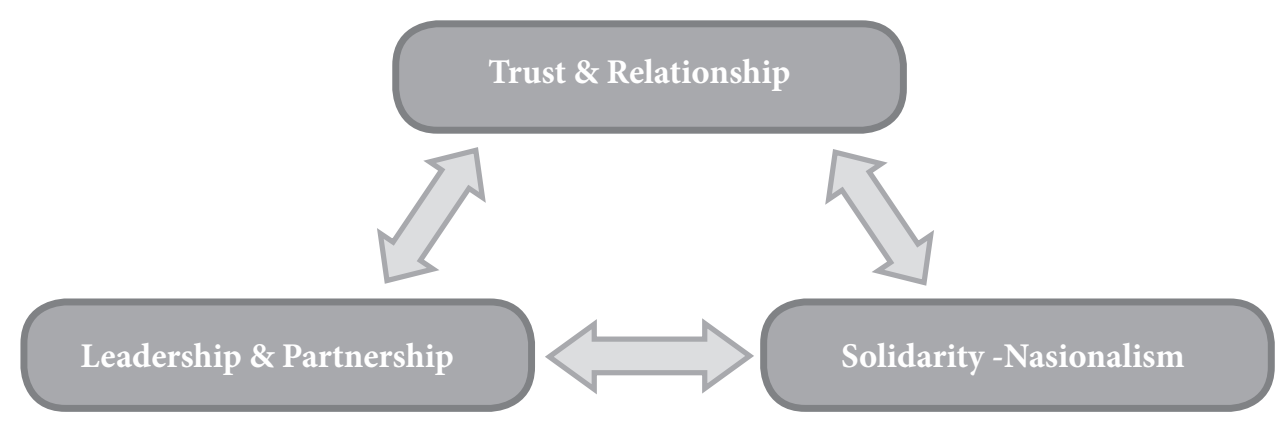

Gambar 8: Segi Tiga Moralitas Pertambangan untuk Indonesia Incorporated

32 Dapat dibaca A. Appadorai, The Substance of Politics Ninth Edition, Oxford University Press, Amen House, London E.C.4, 1961 p. 63. Warren, Leinenweber and Andersen, Our Democary at Work, Second Edition, Prentice-Hall, INC, Englewood Cliffs, N.J., 1967, p.477-480. United States Information service, Embassy of the United States ff America, Deklarasi Kemerdekaan, 200 Tahun Undang- Undang Dasar Amerika Serikat, tth. H. 1-6. Philip Selznick, Law, Society, and Industrial Justic, Russel Sage Foundation, 1969; I.T. Smith and Sir John C. Wood, Industrial Law, Butterworths, London, 1980; S. Takdir Alisjahbana (Ed), Dasar-dasar Kerisis Semesta dan Tanggung Jawab Kita, Dian Rakyat, Jakarta, 1984; dan Y.B. Mangunwijaya, Teknologi dan Dampak Kebudayaannya, Vo. I dan II, Yayasan Obor Indonesia, Jakarta, 1993. 


\section{Menata Pertambangan yang Meneguhkan Negara Kesejahteraan}

\section{Dalam semangat mewujudkan Indonesia Incorporated dibutuhkan langkah} mengkonstruksi hukum yang mampu mendorong percepatan realisasi ketentuan Pasal 33 UUD 1945. Membuat legal framework di bidang perekonomian secara tepat dan kontekstual bagi kesejahteraan rakyat merupakan pilihan solutif. Mengingat tata kelola tambang selama ini memberikan data yang sangat memprihatinkan, antara lain: (a) memburuknya kualitas lingkungan akibat pertambangan; (b) kesenjangan ekonomi semakin menganga; (c) bagi hasil yang tidak proporsional antara pusat dan daerah; (d) kemiskinan meningkat di daerah kaya tambang; (e) konflik sosial yang terus mewarnai dunia pertambangan; (e) penguasaan areal tambang yang tidak sesuai dengan hukum (UU Minerba, UU Agraria, UU Kehutanan, UU Perkebunan, dan UU Konservasi Tanah); (f) pelanggaran tata ruang di bidang pertambangan (merujuk UU No. 26 Tahun 2007 tentang Penataan Ruang); (g) tumpang tindih regulasi antara pengaturan pertambangan dengan pemerintahan daerah (UU Minerba vs UU Pemda); (h) pelanggaran hukum pertambangan secara sengaja maupun akibat ketidakpahaman (seperti pengabaian pengenaan jaminan pertambangan, reklamasi pasca tambang, dan jasa lingkungan); (i) meluasnya pungutan liar; dan (j) degradasi lingkungan yang semakin masif. ${ }^{33}$

Untuk itulah tata kelola pertambangan, meminjam bahasa Alan Gart saatnya dikonstruksi dalam konsep RDR, yaitu: Regulation-Deregulation-Reregulation. ${ }^{34}$ RDR ditawarkan mampu memberikan ruang dinamik menata sektor pertambangan

33 Berbagai bahan pemberitaan mengenai data ini dapat diikuti dari beragam media massa seperti: Tempo, "Lobi Emas Freeport-Istana", 19-25 Oktober 2016. Tempo, Goyang Mundur Setya, 21-27 Desember 2016. Tempo, "Morat Marit Paket Ekonomi", 11-17 Juli 2016. Times, "Bumi Meleleh", 8-14 Juni 2015. Sindo Weekly, "Uji Nyali Freeport", 5 Maret 2017, dan ikuti pemberitaan Koran KOMPAS, Republika sepanjang tahun 2017 ini saja akan dapat diketahui betapa memburuknya tata kelola pertambangan nasional.

34 Alan Gart, Regulation, Deregulation, Reregulation: The Future of the Banking, Insurance, and Securities Industries, John Wiley \& Sons, Inc, 1994. RDR pada mulanya memang hanya disodorkan untuk merespon percepatan gerak dunia perbankan, asuransi dan securities industries dengan pangsa pasarnya yang terus bergerak progresif Robert H. Lauer, Perspektif tentang Perubahan Sosial, (Terjemahan Alimandan S.U.), Rieneka Cipta, Jakarta, 1993, h. 409-415, CSIS, op.cit h. 59-117. Jimoh Omo-Fadaka, Development From Within, Dialogue, Vol. 11 No. 2, 1978, h. 59. 
dengan ketepatan pengambilan kebijakan ekonomi pada laju ekspresif GCG (Good Corporate Governance) dengan pijakan regulasi yang selalu tepat. William Safire dalam karyanya The Right Word in The Right Place at The Right Time mengajarkan perlunya legal framework pertambangan yang: tepat kata (perumusannya), tepat tempat (wilayahnya), dan tepat waktunya. ${ }^{35}$ Perpaduan konsep "DRD” dan "tiga ketepatan" dapat digambarkan sebagai berikut:

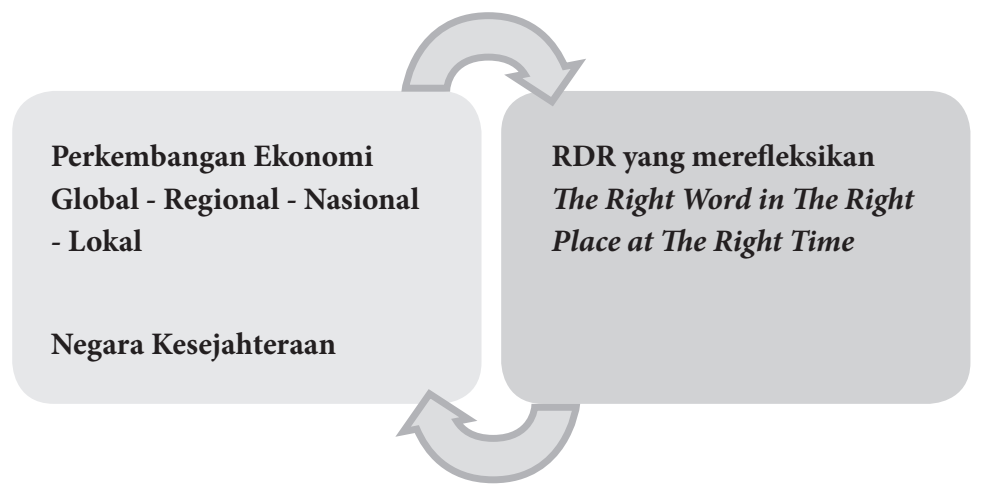

Gambar 9: RDR Alan Gart dan Tiga Ketepatan William Safire

RDR dengan prinsip “Tiga Ketepatan” merupakan tuntutan tata kelola pertambangan yang berada dalam kerangka welfare state sebagaimana diamanatkan UUD 1945. Rekonstruksi norma tata kelola pertambangan yang tersebar di bidang investasi, market economy, korporasi, moda transportasi, distribusi, perbankan, keuangan, asuransi, industri, perdagangan, ekspor impor, ${ }^{36}$ dan sektor lainnya mutlak segera dilakukan, karena terdapat cenderungan hanya untuk "mengeruk kekayaan alam demi peningkatan PAD (pendapatan asli daerah)" . Potret ini sudah diketahui publik, sehingga perlu diadakan evaluasi (deregulasi) sekaligus reregulasi.

Rekonstruksi terhadap perumusan, penetapan dan pelaksanaan kebijaksanaan dapat dimengerti dari konsep legal policy yang dikemukankan Petrazycki: ${ }^{37}$ "The

35 William Safire, The Right Word in the Right Place at the Right Time, Simon \& Schuster, New York, 2004, h. 240-287.

36 Joseph A. Schumpeter, Capitalism, Socialism \& Democracy, Pustaka Pelajar, 2003. Peter, Senge, at.all., The Necessary Revolution: How Individuals and Organizations Are Working Together to Create a SustainableWorld, Nicholas Brealey, London, 2008. Dani W. Munggoro, dkk., Menggugat Ekspansi Industri Pertambangan di Indonesia, LATIN, Bogor, 1999. P. Dvorin, Eugene and Robert H. Simmons, Dari Amoral sampai Birokrasi Humanisme, Prestasi Pustakaraya, Jakarta, 2000.

37 Alan B. Mountjoy, Industrialisasi dan Negara-negara Dunia Ketiga, (Alih Bahasa D.H. Gulo), Bina Aksara, Jakarta, 1983. Margareth M. Poloma, Sosiologi Kontemporer (Terjemahan YASOGAMA), Raja Grafindo Persada, Jakarta, 1994, h. 380, 387-389. J.B.J.M. Berge Ten, Bescherm- 
essence of the problem of the policy of law consists in scientifically justified prediction of the effect if certain legal enactments are introduce and elaborating principles which will bring about some desirable effect". Perputaran pembaruan hukum di sektor pertambangan dengan RDR yang dikaitkan dengan kebijakan publik perekonomian suatu negara, dapat dituangkan dalam siklus skematis di bawah ini:

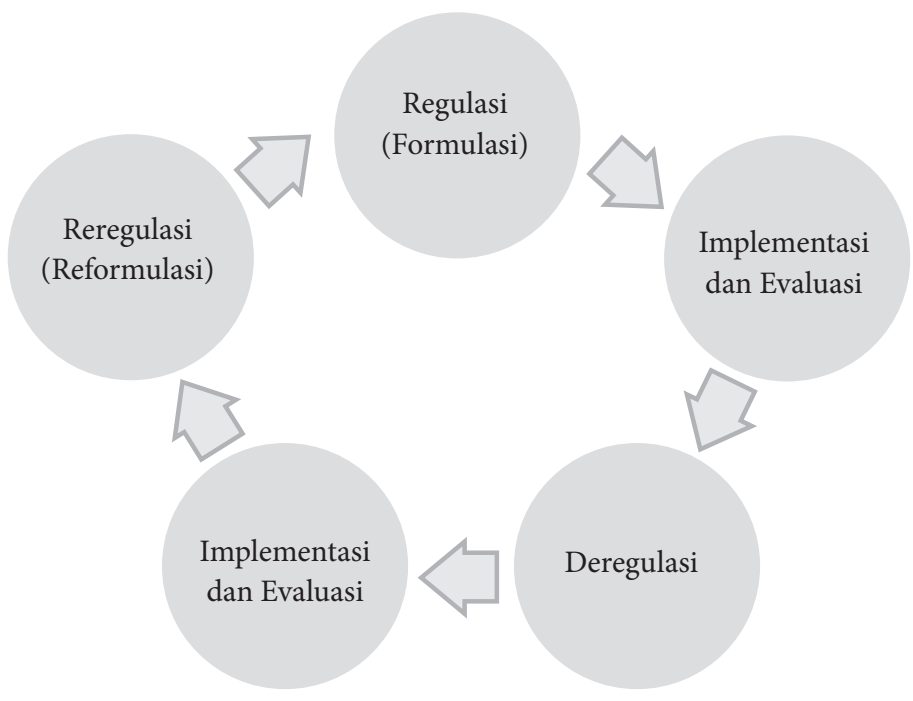

\section{Gambar 10: Perputaran Pembaruan RDR Pertambangan Berkelanjutan}

Dewasa ini RDR telah dilakukan untuk melaksanakan GCG di bidang pertambangan. Penerbitan Peraturan Pemerintah No. 1 Tahun 2017 tentang Perubahan Keempat Atas PP Nomor 23 Tahun 2010 Tentang Pelaksanaan Kegiatan Usaha Pertambangan Mineral dan Batubara, tertanggal 11 Januari 2017 berikut aturan turunannya, merupakan penjelmaan konsepsi RDR-GCG tata kelola pertambangan. PP No. 1 Tahun 2017 yang ditindaklanjuti dengan hadirnya Permen ESDM No. 5 Tahun 2017 tentang Peningkatan Nilai Tambah Mineral melalui Kegiatan Pengolahan dan Pemurnian Mineral di dalam Negeri dan Peraturan Menteri ESDM No. 6 Tahun 2017 tentang Tata Cara dan Persyaratan Pemberian Rekomendasi Pelaksanaan Penjualan Mineral ke Luar Negeri Hasil Pengolahan dan Permurnian, dapat dipahami sebagai keseriusan Pemerintah mengurai ragam kepentingan pertambangan. ${ }^{38}$

ingtegendeoverheid, W.E.J. Tjeenk Willink Zwolle, 1993. Velix V.Wanggai, Pembangunan Untuk Semua: Mengelola Pembangunan Regional a la SBY, Indomultimedia Communication Group, 2012. Richard A. Wasserstrom, Morality and the Law, Wadsworth Publishing Company, Inc., Bellmont, California, 1971.

38 Pengaturan tambang (terutama kasus Freeport) mengenai kewajiban divestasi 51\% merupakan bentuk reregulasi pertambangan. Masalah divestasi 51\% ini berdasarkan Pasal 24 
RDR untuk pertambangan di negara kesejahteraan dalam bingkai Indonesia Incorporated, dapat digambarkan seperti di bawah ini:

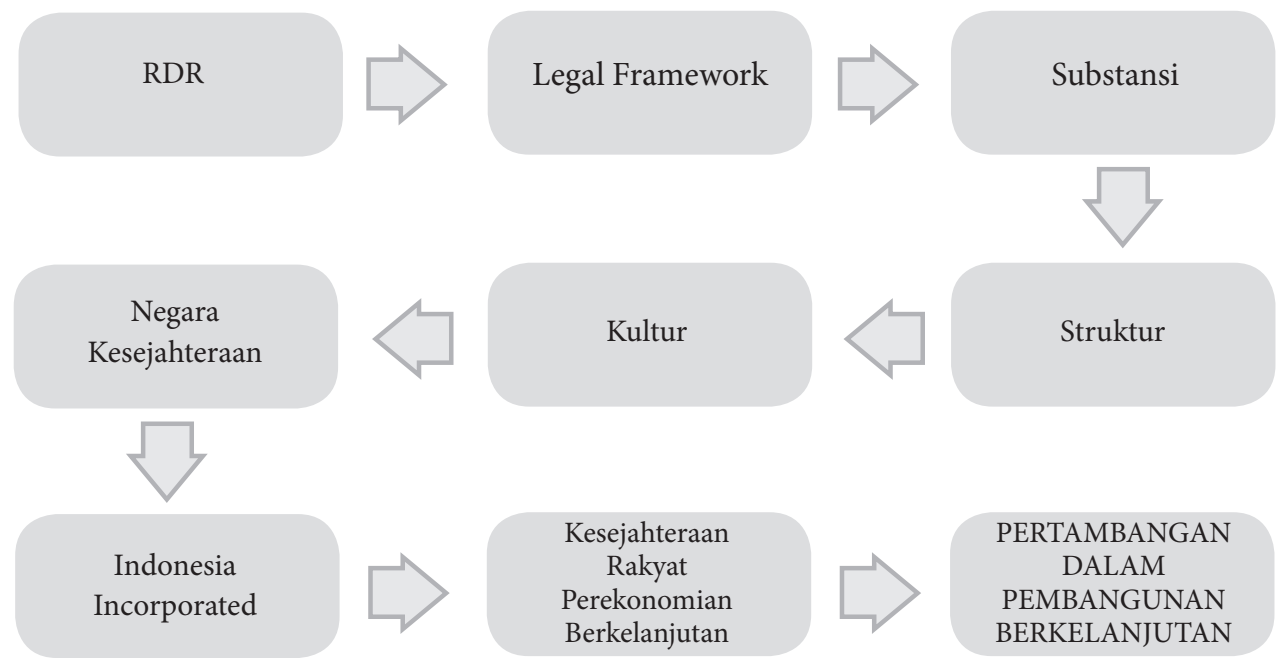

Gambar 11: Rute Perwujudan RDR dalam Pertambangan Berkelanjutan Indonesia Incorporated

Apa yang menjadi ukuran suatu negara dinamakan negara kesejahteraan? Secara teoritis, menurut Bismarck, keberhasilan penerapan Negara Kesejahteraan diukur dari tiga variabel, yaitu: ${ }^{39}$ (1) pemenuhan kebutuhan biologis warga, (2) pemenuhan kebutuhan pengembangan diri dan sosial warga serta (3) ketersediaan fasilitas umum bagi warga. ${ }^{40}$ Kesejahteraan akan tercipta secara teoritis bersentuhan dengan tiga dimensi: politik, sosial, dan ekonomi. Indonesia Inc. sejatinya menggulirkan konsepsi bahwa negara harus hadir membuat kebijakan ekonomi untuk kesejahteraan rakyat, serta membuka akses secara adil dan keterbukaan pemerintahan (openbaar bestuur). ${ }^{41}$

Kontrak Karya (KK) tahun 1991, sebenarnya harus tuntas tahun 2011. Dalam KK ini, Freeport dibahasakan oleh hukum telah melakukan wanprestasi, mengabaikan isi perjanjian yang telah disepakati sendiri. Hadirnya kebijakan pertambangan yang telah diperbuat Pemerintah dimaksud secara konstitusional hendak memperkuat peneguhan diri sebagai negara kesejahteraan dengan semangat Indonesia Incorporated terus dimatangkan. Perkembangan dinamik fungsi pemerintah dalam perekonomian negara kesejahteraan yang berkomitmen mewujudkan Indonesia Incorporated telah membawa catur fungsi negara berjalan paralel.

39 Tri Widodo, "MEA dan Jawa Timur", dalam Soekarwo, Soekarwo dkk., Pintu Gerbang MEA 2015 Harus Dibuka, Prenada Media Group, Jakarta, 2016, h. 39-57.

40 Mahmud Syaltout, “Negara Kesejahteraan dan Posisi Jawa Timur”, dalam Soekarwo dkk., Pintu Gerbang MEA 2015 Harus Dibuka, Prenada Media Group, Jakarta, 2016, h. 87-90.

41 James Garvey, 20 Karya Filsafat Terbesar, Kanisius, Yogyakarta, 2010. H.L.A. Hart, Law LibertyAnd Morality: Hukum, KebeasanDan Moralitas, Genta Publishing, PO.BOX 1095 YK-55000, 2000. 
Kristalisasi konsepsi GCG yang implementatif untuk pertambangan yang mensejahterakan rakyat saya tawarkan dengan rumusan berikut ini:

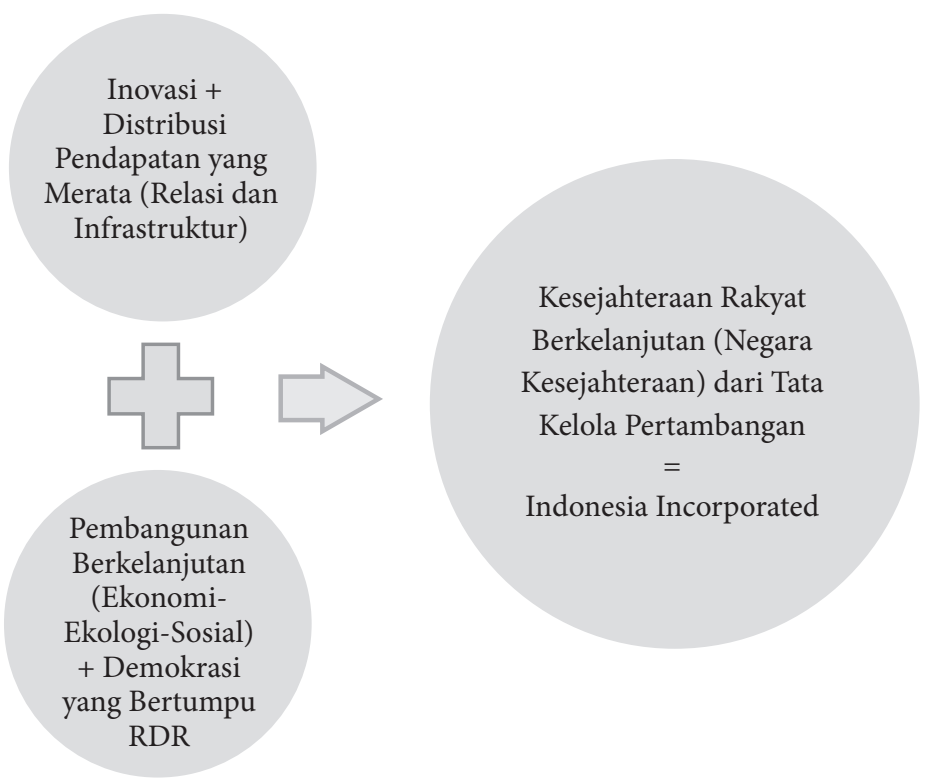

\section{Gambar 12: Implementasi GCG dan Ekonomi Inovasi dalam Tata Kelola Pertambangan}

Indonesia Incorporated

Pertambangan dalam Indonesia Incorporated harus dikelola secara GCG melalui paradigma corporate philosophy and corporate culture for sustainable growth dengan pemerintahan yang integratif. ${ }^{42}$ Tata kelola ini untuk mewujudkan negara kesejahteraan berlegitimasi RDR seperti gambar berikut ini:

Paul Hawken, The Ecology of Commerce: A Declaration of Sustainability, Harper-Business, New York, 1993. G.W.F. Hegel, Filsafat Sejarah, Pustaka Pelajar, Yogyakarta, 2001. A. Hoogerwert, Ilmu Pemerintahan,Erlangga, Jakarta, 1983. Ten Berge, at.all., Verklarendwoordenboek Openbaar Bestuur, Tjeenk Willink, 1992. CH, J. Enschede, De Macht Van De Rechtswetenschap: Overheidsbeleiden maatschappijwetenschappen, Universitaire PersLeiden, Kluwer-Deventer, 1979.

42 Bandingkan Karl R. Popper, Masyarakat Terbuka dan Musuh-musuhnya, Pustaka Pelajar, Yogyakarta, 2001. John Rawls,, A Theory of Justice: Teori Keadilan, Dasar-dasar Filsafat Politik untuk Mewujudkan Kesejahteraan Sosial dalam Negara, Pustaka Pelajar, Yogyakarta, 2011, h. 234-289. Y.B. Mangunwijaya, Teknologi dan Dampak Kebudayaannya, Volumen II, Yayasan Obor Indonesia, Jakarta, 1985. Alfred Marshall, Principles Of Economics, Macmillan \& Co Ltd, London, 1959. Donella Meadows,, at.all., Batas-Batas Pertumbuhan, Gramedia, Jakarta, 1982. Reihard Mohn, An Age of New Possibilities: How Humane Values andan Entrepreneurial Spirit Will Lead Us into the Future, Crown Publishers, New York, 2004. Baca pula Aseem Shrivastava and Ashish Kothari, Churning The Earth, Penguin Book, India, 2012. Thomas Crump, How The Industrial Revolution Change The World, Robinson, UK, 2010. Robert D. Kaplan, The Revenge of Geography, Random House Trade Paperbacks, New York, 2012. Chris Goodall, Ten Technologies To Fix Energy and Climate, Mixed Sources, London, 2008, h. 76-98. 


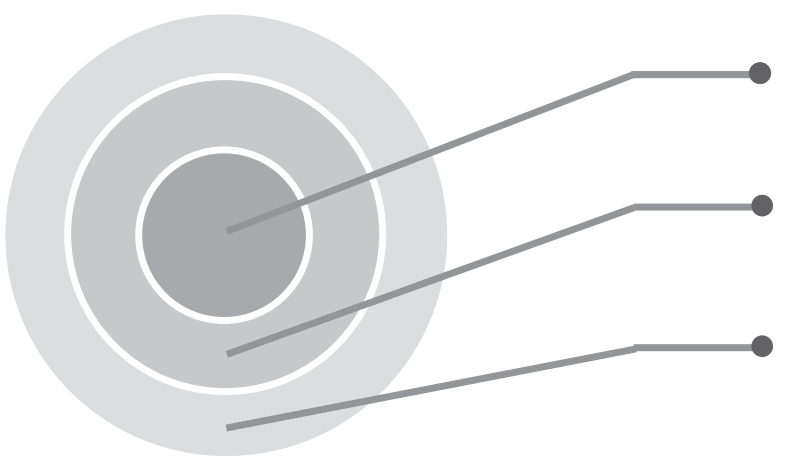

Kebutuhan Rakyat sebagai Sumber

Legitimasi yang PARTISIPATORIS

Perwujudan tata kelola

pemerintahan model GCG

Kesejahteraan Rakyat dengan

RDR yang meneguhkan realisasi

INDONESIA INCORPORATED

Gambar 13: Lingkar Esensial GCG-RDR-Indonesia Incorporated dalam Negara Kesejahteraan

Negara Kesejahteraan berdasarkan UUD 1945 melakukan tata kelola pertambangan ${ }^{43}$ sesuai dengan Public Interest GCG-RDR-Indonesia Incorporated sebagaimana Gambar ini:

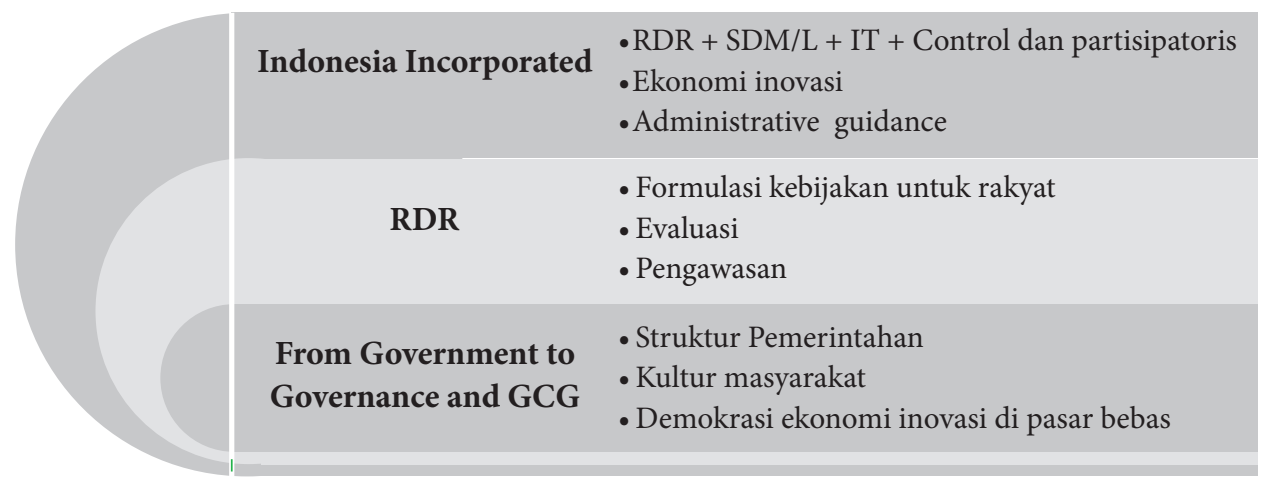

\section{Gambar 14: Konstelasi Tata Kelola Tambang dalam Perwujudan GCG-RDR-Indonesia}

\section{Incorporated}

Untuk merealisir itu semua dibutuhkan manajemen kepemimpinan yang harus mampu menjadi generator perubahan besar bagi kesejahteraan rakyat yang berbasis public-participation. Pertambangan di NKRI harus ditata kelola dengan berpijak pada Pancasila, UUD 1945, NKRI dan Bhinneka Tunggal Ika:

43 Lihat Tony Evans, Human Rights in The Global Political Economy, Lynne Rienner Publishers, London, 2011. Armando Mahler, dan Nurhadi Sabirin, Dari Grasberg Sampai Amamapare, PT. Gramedia Pustaka Utama, Jakarta, 2008. Daron Acemoglu, dan James A. Robinson, Mengapa Negara Gagal, Awal Mula Kekuasaan, Kemakmuran, dan Kemiskinan, PT. Elex Media Komputindo, New York, 2012. N.E. Algra, at., all., Profiel van het Recht, Kluwer, 1999. Erich Fromm, Akar Kekerasan, Analisis Sosio-Psikologis atas Watak Manusia, Pustaka Pelajar, Yogyakarta, 2000, h. 145-256. 


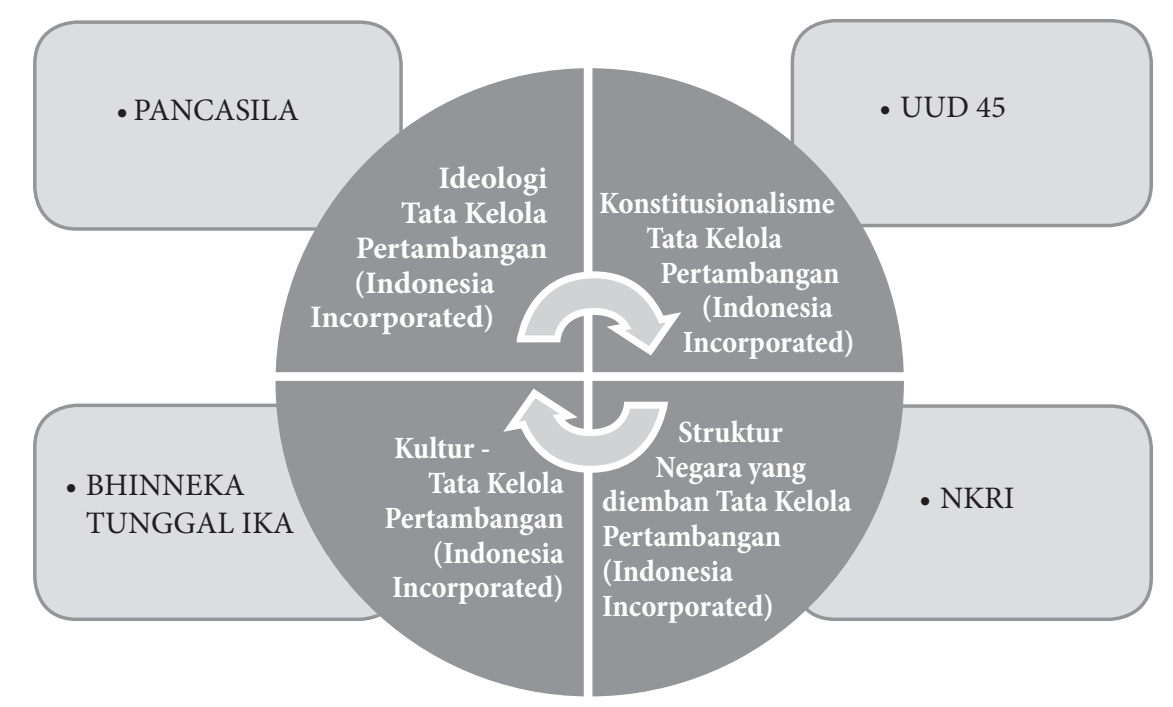

\section{Gambar 15: Pijakan Tata Kelola Pertambangan Berkelanjutan}

Dengan demikian akan terwujud tata kelola pertambangan yang partisipatoris dalam setiap penentuan kebijakan, perizinan, dan pengendaliannya. Investasi pertambangan dilaksanakan secara terbuka dengan siklus RDR yang menjunjung tinggi nilai-nilai kebangsaan dan keadilan. Tidak boleh lagi ada daerah kaya tambang yang rakyatnya miskin. 


\section{Penutup}

\section{Kesimpulan:}

a. Pertambangan untuk kesejahteraan rakyat adalah amanat konstitusional UUD 1945 yang harus dikelola melalui perumusan legal framework pertambangan yang: tepat kata (perumusannya), tepat tempat (wilayahnya), dan tepat waktunya sedasar konsepsi GCG-RDR-Indonesia Incorporated.

b. Pemikiran konseptual dan implementatif tata kelola pertambangan untuk mewujudkan Indonesia Incorporated yang berorientasi kepada kemakmuran rakyat sebagaimana dinormakan UUD 1945 mempersyaratkan perlakuan secara konsisten prinsip-prinsip bekerjanya GCG yang ditopang oleh mekanisme RDR, SDM dan leadership yang profesional, pemanfaatan Teknologi Informasi secara fungsional, serta kontrol publik yang demokratis.

\section{Saran:}

a. Pengaturan sektor pertambangan harus dirumuskan ulang untuk memperkuat perekonomian nasional di kancah global dengan orientasi utama tata kelola tambang bagi "sebesar-besar kemakmuran rakyat" guna mengembalikan karakter NKRI sebagai negara (hukum) kesejahteraan.

b. Dalam kerangka Indonesia Incorporated, meminjam kata-kata Peter Senge, ${ }^{44}$ merekonstruksi regulasi pertambangan sesungguhnya the necessary revolution untuk melakukan tata kelola yang berkelanjutan dengan menetapkan kebijakan sesuai pesan utama Pasal 33 UUD 1945: “untuk sebesar-besar kemakmuran rakyat".

Akhirnya, sebagai negara kaya tambang, Indonesia seyogianya mengambil prakarsa menyediakan Jalan Baru perwujudan Negara Kesejahteraan dari sektor pertambangan. Publik menyadari bahwa masa depan memang menyediakan pikiran baru (new thinking), pilihan baru (new choices) dan awal baru (new beginnings), tetapi masa depan baru itu dimulai dari komitmen dan konsistensi leader dalam mengambil keputusan. Suara tata kelola pertambangan yang menyejahterakan rakyat akan terus menggema dalam wadah Indonesia Incorporated dengan hukum yang to create a sustainable development.

44 Peter Senge,, at.all., The Necessary Revolution: How Individuals and Organizations Are Working Together to Create a SustainableWorld, Nicholas Brealey, London, 2008. 


\section{DAFTAR PUSTAKA}

Acemoglu, Daron dan James A. Robinson, Mengapa Negara Gagal, Awal Mula Kekuasaan, Kemakmuran, dan Kemiskinan, PT. Elex Media Komputindo, New York, 2012.

Algra, N.E., at., all., Profiel van het Recht, Kluwer, 1999.

Al Gore, The Future, A Random House Group Company, 2013.

Appadorai, A. , The Substance of Politics ${ }_{L}$ Ninth Edition, Oxford University Press, Amen House, London E.C.4, 1961.

Ash Garton, Timothy, Free World: America, Europe and the Surprising Future Of The West, Random House, Inc., New York, 2004.

Asnawi, Ahmad, Sejarah Para Filsuf Dunia: 90 Pemikir Terhebat Paling Berpengaruh di Dunia, Indoliterasi, Yohyakarta, 2014.

Berge Ten, at.all., Verklarendwoordenboek Openbaar Bestuur, Tjeenk Willink, 1992.

Boulle, Laurence, The Law Of Globalization An Introduction, Wolters Kluwer, 2009.

Brenner, M. Harvey, Pengaruh Ekonomi Terhadap Perlaku Jahat dan Penyelenggaraan Perailan Pidana, CV. Rajawali, Jakarta, 1986.

Budiardjo, Miriam, Dasar-Dasar Ilmu Politik, Gramedia, Jakarta, 2015.

Budianta, Eka, Moral Industri, Laporan dan Renungan, Pustaka Sinar Harapan, Jakarta, 1999.

Burnside, Craig (Editor), Fiscal Sustainability in Theory and Practice, The World Bank Washington D.C., 2005.

Capra, Fritjof, Titik Balik Peradaban: Sains, Masyarakat dan Kebangkitan Kebudayaan, Yayasan Bentang Budaya, Yogyakarta, 1997.

Carter, Graydon, What We've Lost, Little, Brown, 2004.

Collison, Kerry B., Indonesian Gold, Sid Harta Publishers, Australia, 2012.

Crump, Thomas, How The Industrial Revolution Change The World, Robinson, UK, 2010.

Diamond, Jared, Guns, Germs \& Stell, Gramedia, Jakarta, 2013.

-------, Collapse, Gramedia, Jakarta, 2014.

-------, The World Until Yesterday, Gramedia, Jakarta, 2015

Dweck, Carol S., Cara Baru Melihat Dunia Dan Hidup Sukses Tak Berhingga, Serambi Ilmu Semesta, 2007. 
Budi Sulistyo, dkk., MDGs Sebentar Lagi: Sanggupkah Kita Menghapus Kemiskinan Di Dunia?, Gramedia, Jakaarta, 2010.

E. Visser, Leontine dan Amapon Jos Marey, Bakti Pamong Praja Papua, Kompas, Jakarta, 2008.

Enschede, CH, J., De Macht Van De Rechtswetenschap: Overheidsbeleiden Maatschappijwetenschappen, Universitaire PersLeiden, Kluwer-Deventer, 1979. Evans, Tony, Human Rights in The Global Political Economy, Lynne Rienner Publishers, London, 2011.

Foucault, Michel, Kegilaan dan Peradaban, Madness and Civilization, Ikon Teralitera, Yogyakarta, 2002.

Friedman, George, The Next 100 years, Anchor Books, New York, 2009.

Friedman, Thomas L., The World Is Flat: Sejarah Ringkas Abad Ke-21, Dian Rakyat, Jakarta, 2006.

Friedmann, W., The State And The Rule Of Law in a Mixed Economy, Stevens \& Sons, London, 1971.

Friedmann, Wolfgang Law in a Changing Society, Penguin Books,England, 1972.

Fukuyama, Francis, Kemenangan Kapitalisme dan Demokrasi Liberal, Qalam, Yogyakarta, 2001.

-------, The End of History and The Last Man, Qalam, Yogyakarta, 2003.

-------, Trust: Kebajikan Sosial Dan Penciptaan Kemakmuran, Qalam, Yogyakarta, 2010.

-------, Political Order and Political Decay: From The Industrial Revolution To The Globalization of Democracy, Farrar, Straus and Giroux, New York, 2014.

Fromm, Erich, Akar Kekerasan, Analisis Sosio-Psikologis atas Watak Manusia, Pustaka Pelajar, Yogyakarta, 2000.

Gaol, CHR. Jimmy L., A to Z, Human Capital: Manajemen Sumber Daya Manusia: Konsep, Teori, Dan Pengembangan Dalam Konteks Organisasi Publik Dan Bisnis, PT. Grasindo, Jakarta, 2014.

Gart, Alan, Regulation, Deregulation, Reregulation: The Future of the Banking, Insurance, and Securities Industries, John Wiley \& Sons, Inc, 1994.

Garvey, James, 20 Karya Filsafat Terbesar, Kanisius, Yogyakarta, 2010.

Giddens, Anthony, Jalan Ketiga: Pembaruan Demokrasi Sosial, Gramedia Pustaka Utama, Jakarta, 1999. 
---------, The Constitution of Society: Teori Strukturasi untuk Analisis Sosial, Pedati, Pasuruan.

Gill, Indermit S., and Todd Pugatch, At the Frontlines of Development Reflection From the World Bank, The World Bank, D.C., 2005.

Goodman, Amy, The axception to the rulers: exposing oily politicians, war profiteers, and the medis that love them, Hyperion, New York, 2004.

Goldsmith, James, Perangkap, Yayasan Obor Indonesia, Jakarta, 1996.

Goodall, Chris, Ten Technologies To Fix Energy and Climate, Mixed Sources, London, 2008.

Goldberg, Jonah, Liberal Fascism: The Secret History of the American Left from Mussolini to the Politics of Meaning, Doubleday, 2007.

Gorman, Tom, The Complete Ideal's Guides, Economics, Prenada, 2009.

Guell, Robert C., Issues in Economics Today, McGraw-Hill, 2012.

Habermas Jurgen, Teori Tindakan Komunikatif Buku Satu: Rasio dan Rasionalisasi Masyarakat, Kreasi Wacana,Bantul, 2012.

Hage, Jerald and Charles H. Powers, Post-Industrial Lives: Roles and Relationships in the 21st Century, SAGE, London, 1992.

Hart, H.L.A., Law LibertyAnd Morality: Hukum, KebeasanDan Moralitas, GENTA PUBLISHING, PO.BOX 1095 YK-55000, 2000

Hatta, Mohammad, Penjabaran Pasal 33 UUD '45, Mutiara, Jakarta, 1980.

-------, Politik, Kebangsaan, Ekonomi (1926-1977), Kompas, 2015.

-------, Membangun Koperasi dan Koperasi Membangun: Gagasan \& Pemikiran, Kompas, 2015.

Haryanto, Ignatius dkk (Editor), Kehutanan Indonesia Pasca Soeharto: Reformasi Tanpa Perubahan, Pustaka Latin, Jakarta, 1998.

H. Lauer, Robert, Perspektif tentang Perubahan Sosial, (Terjemahan Alimandan S.U.), Rieneka Cipta, Jakarta, 1993.

Hayes, Declan, Japan's Big Bang: The Regulation and Revitalization of the Japanese Economy, Tuttle, Boston, 2000.

Hawken, Paul, The Ecology of Commerce: A Declaration of Sustainability, HarperBusiness, New York, 1993.

Heemskerk W.H., Vorm en Wezen, Uitgeverij LEMMA B.W., Utrecht, 1991.

Hegel, G.W.F., Filsafat Sejarah, Pustaka Pelajar, Yogyakarta, 2001. 
Hettne, Bjorn, Teori Pembangunan Dan Tiga Dunia, PT. Gramedia Pustaka Utama, Jakarta, 2001.

Hoogerwert, A., Ilmu Pemerintahan, Erlangga, Jakarta, 1983.

Jacques Laffont, Jean, Regulation and Development, Cambridge University Press, UK, 2005.

J. Pierce, JR, Richard, Regulated Industries In A Nutshell, West Publishing CO, 1984. Janow, Merit E, at.all., The WTO: Governance, Dispute Settlement \& Developing Countries, Juris Publishing, Inc., 2008.

Kaplan, Robert D. The Revenge of Geography, Random House Trade Paperbacks, New York, 2012.

Kementerian Lingkungan Hidup, Himpunan Hasil-hasil Putusan Pengadilan Tentang Tindak Pidana Lingkungan, KLH, Jakarta, 2007.

Kim, Hwan-Yun, Local Government Finance and Bond Markets, Asian Development Bank, 2003.

Kohli, Atul, State-Directed Development, Political Power and Industrialization in the Global Periphery, Cambridge University Press, 2004.

Kramer, Peter D, Against Depression, Viking Penguin, 2005.

Iida, Akira, Paradigm Theory \& Policy Making: Reconfiguring The Future, TUTLE, 2004.

Lembaga Administrasi Negara dan Badan Pengawasan Keuangan dan Pembangunan, Akuntabilitas dan Good Governance, Jakarta, 2000.

LP3ES, Karya Lengkap Bung Hatta, Jakarta, 2015.

Loury, Glenn C., at.,all., Ethnicity, Social Mobility and Public Policy, Cambridge University Press, 2005.

Lubbers, Ruud, at.all., Inspiration for Global Governance: The Universal Declaration of Human Rights and the earth Charter, Kluwer, 2008.

Mahler, Armando dan Nurhadi Sabirin, Dari Grasberg Sampai Amamapare, PT. Gramedia Pustaka Utama, Jakarta, 2008.

Mangunwijaya, Y.B., Teknologi dan Dampak Kebudayaannya, Volumen II, Yayasan Obor Indonesia, Jakarta, 1985.

Marshall, Alfred, Principles of Economics, Macmillan \& Co Ltd, London, 1959.

Meadows, Donella, at.all., Batas-Batas Pertumbuhan, Gramedia, Jakarta, 1982.

Meene van de, Ineke and Benjamin van Rooij, Access to Justice And Legal Empowerment: Making the Poor Central in Legal Development Co-operation. Leiden University Press. 
Mohn, Reihard, An Age of New Possibilities: How Humane Values andan Entrepreneurial Spirit Will Lead Us into the Future, Crown Publishers, New York, 2004.

Mousis, Nicholas, Guide to European Policies, 6th edition, European Study Service, BP29-B-1330 Rixensart, Belgium, 2000.

Munggoro, Dani W., dkk., Menggugat Ekspansi Industri Pertambangan di Indonesia, LATIN, Bogor, 1999.

Numberi, Freddy, Quo Vadis Papua, PT. Buana Ilmu Populer, Jakarta, 2013.

Omo-Fadaka, Jimoh Development From Within, Dialogue, Vol. 11 No. 2, 1978.

P. Dvorin, Eugene and Robert H. Simmons, Dari Amoral sampai Birokrasi Humanisme, Prestasi Pustakaraya, Jakarta, 2000.

Pierce, Richard J. JR, Regulated Industries In A Nutshell, West Publishing CO, 1984. Popper, Karl R., Masyarakat Terbuka dan Musuh-musuhnya, Pustaka Pelajar, Yogyakarta, 2001.

Posner, Richard A., Economic Analysis Of Law, Little, Brown and Company, 1992.

Qrebech, Peter, at.all., The Role of Customary Law in Sustainable Development, Cambridge University Press, 2005.

Rawls, John, A Theory of Justice: Teori Keadilan, Dasar-dasar Filsafat Politik untuk Mewujudkan Kesejahteraan Sosial dalam Negara, Pustaka Pelajar, Yogyakarta, 2011.

Rourke, Francis E., Bureaucracy Politics, and Public Policy, Little, Brownand Company, Boston, 1976.

Roy, R. Crince Le, Bestuur en Norm, Kluwer-Deventer, 1986.

Safire, William, The Right Word in the Right Place at the Right Time, Simon \& Schuster, New York, 2004.

Sawer, Geoffrey, Law in Society, Oxford at the Clarendum, London. 1973.

Samuel, Geoffrey, The Foundations of Legal Reasoning, MAKLU, 1994.

Schumpeter, Joseph A., Capitalism, Socialism \& Democracy, Pustaka Pelajar, 2003.

Schlosser,Eric, Command And Control, The Penguin Press, New York, 2013.

Selznick, Philip, Law, Society, and Industrial Justice, Russel Sage Foundation, 1969

Senge, Peter, at.all., The Necessary Revolution: How Individuals and Organizations Are Working Together to Create a SustainableWorld, Nicholas Brealey, London, 2008.

Schendler, Auden, GETTING Green Done, Hard Truths from the Front Lines of the Sustainability Revolution, Public Affairs, New York, 2009. 
Shrivastava, Aseem and Ashish Kothari, Churning The Earth, Penguin Book, India, 2012.

Smith, T. and Sir John C. Wood, Industrial Law, Butterworths, London, 1980

Soekarwo dkk, Pakde Karwo Pintu Gerbang MEA 2015 Harus Dibuka, Kencana, Prenada Media Group, Jakarta, 2015.

-------, dkk, Pintu Gerbang MEA 2015 Harus Dibuka, Kencana, Prenada Media Group, Jakarta, 2015.

------, Administrative Reform: Birokrasi Itu Melayani, Kencana, Prenada Media Group, Jakarta, 2016.

Straker, David, The Quality Conspiracy, Gower, 1998.

Stein, Peter, Legal Evolution: The Story Of An Idea, Cambridge University Press, 1980.

Suharto, Frento T. Menambang Kekayaan Dari Bisnis Emas Tanpa Mengeruk Alam, PT Elex Media Komputindo, Jakarta, 2014.

Sukarno, Indonesia Menggugat: Pidato Pembelaan Bung Karno Dimuka Hakim Kolonial, SK. Seno, Djakarta, 1956.

Tantular, Mpu, Kakawin Sutasoma, Komunitas Bambu, Jakarta, 2009, h. 538-539.

Ten, Berge J.B.J.M., Beschermingtegendeoverheid, W.E.J. Tjeenk Willink Zwolle, 1993.

The Wordlwatch Institute, State Of The World Our Urban Future, W.W. Norton \& Company, New York-London, 2006.

Wanggai, Velix V., PembangunanUntuk Semua: Mengelola Pembangunan Regional a la SBY, Indomultimedia Communication Group, 2012.

Warren, Leinenweber and Andersen, Our Democary at Work, Second Edition, Prentice-Hall, INC, Englewood Cliffs, N.J., 1967.

Wasserstrom, Richard A., Morality and the Law, Wadsworth Publishing Company, Inc., Bellmont, California, 1971

W.H., Heemskerk, Vorm en Wezen, Uitgeverij LEMMA B.W., Utrecht, 1991.

Wijoyo, Suparto, Ilmu Hukum, Airlangga Universy Press, Surabaya, 2005.

------, Reklamasi itu Kebutuhan Siapa, Forum Keadilan, No. 22, 16 Oktober 2016.

------, Penyelesaian Sengketa Lingkungan (Environmental Disputes Resolution), AUP, Surabaya, Cetakan Kedua, 2005.

------, Refleksi Matarantai Pengaturan Hukum Pengelolaan Lingkungan Secara Terpadu, AUP, Surabaya, 2005.

------, Karakteristik Hukum Acara Peradilan Administrasi, AUP, Surabaya, Cetakan Kedua, 2005. 
-------, Kusebut Indonesia: Dari Keanekaragaman Menuju Keseragaman Hayati, AUP, Surabaya, 2012.

------, Hukum Perlindungan Lingkungan Hidup, Airlangga University Press, Surabaya, 2017.

Wilcox, Clair, Toward Social Welfare, Richard D. Irwin, Inc, 1969.

Yahya, Arief, Great Spirit, Grand Strategy, Corporate Philosophy, Leadership Architecture, and Corporate Culture for Sustainable Growth, PT. Gramedia, Jakarta, 2013.

Yergin, Daniel, The Quest: Energy, Security, and the Remaking of the Modern World, The Penguin Press, New York, 2011.

Yudhoyono, Susilo Bambang, Selalu Ada Pilihan, Kompas, Penerbit Buku, Jakarta, 2014.

Yoesoef, Abdul Jabar, Jangan Biarkan Asing Kuras Tambang Kita, PT. Elex Media Komputindo, Jakarta, 2011.

Zalasiewics, Jan, The Earth After Us, What Legacy Will Humans Leave In The Rocks?, Oxford University Press, 2008. 